\title{
Synthesis, Structure and Reactivities of Pentacoordinated Phosphorus-Boron Bonded Compounds
}

\author{
Nathan J. O’Brien, ${ }^{[a]}$ Naokazu Kano, ${ }^{*[a, b]}$ Nizam Havare, ${ }^{[a]}$ Ryohei Uematsu, ${ }^{[c]}$ Romain Ramozzi, ${ }^{[c]}$ and \\ Keiji Morokuma ${ }^{\dagger[c]}$
}

\begin{abstract}
The isolation and reactivities of two pentacoordinated phosphorus-tetracoordinated boron bonded compounds were explored. A strong Lewis acidic boron reagent and electronwithdrawing ligand system were required to form the pentacoordinated phosphorus state of the P-B bond. The first compound, a phosphoranyl-trihydroborate, gave a THF stabilised phosphoranyl-borane intermediate upon a single hydride abstraction in THF. This compound could undergo a unique rearrangement reaction, which involved a two-fold ring expansion, to give a fused bicyclic compound or it could act as a mono-hydroboration reagent. The hydroboration reactivity of the intermediate was found to be more reactive towards alkynes over alkenes with good to moderate regioselectivity towards the terminal carbon. The second compound, a phosphoranyl-triarylborate, was found to have different reactivity as it was highly stable towards acids and bases. This is thought to be due to the large bulk around the P-B bond as shown in the crystal structure.
\end{abstract}

\section{Introduction}

The combination of a phosphine and borane gives a phosphineborane $\left(\mathrm{R}_{3} \mathrm{P}-\mathrm{BR}_{3}\right)$ through $\mathrm{P}-\mathrm{B}$ bond formation. ${ }^{[1-4]}$ These compounds have been used as protecting groups for $P$-chiral tertiary phosphines and diphosphines, ${ }^{[5-9]}$ as well as precursors for P-B bond containing polymers. ${ }^{[10-12]}$ More recently, phosphino-boranes, ${ }^{[13]}$ bearing the lower coordinated bond between a tricoordinated phosphorus and a tricoordinated boron atom $\left(R_{2} P-B R_{2}\right)$, have regained attention as they have been

[a] Dr. N. J. O’Brien, Prof. N. Kano, Dr. N. Havare Department of Chemistry, Graduate School of Science The University of Tokyo

7-3-1 Hongo, Bunkyo-ku, Tokyo 113-0033 (Japan)

[b] Prof. N. Kano

Current address: Department of Chemistry, Faculty of Science Gakushuin University

1-5-1 Mejiro, Toshima-ku, Tokyo 171-8588 (Japan) E-mail: naokazu.kano@gakushuin.ac.jp

[c] Dr. R.Uematsu, Dr. R. Ramozzi, Prof. K. Morokuma Fukui Institute for Fundamental Chemistry Kyoto University

Takano-Nishihiraki-cho 34-4, Sakyou-ku, Kyoto 606-8103 (Japan)

$\dagger \quad$ Deceased November 27, 2017

Supporting Information (NMR spectral charts, X-ray crystallographic analysis, and computational details), and the ORCID identification number(s) for the author(s) of this article can be found under: shown to activate $\mathrm{H}_{2}$ and other small molecules ${ }^{[14-17]}$ and to coordinate to metals in a symmetric side-on fashion. ${ }^{[18]}$ Moreover, phosphinoboronate esters $\left(\mathrm{R}_{2} \mathrm{P}-\mathrm{B}(\mathrm{OR})_{2}\right)$ have shown phosphinoboration reactivity to double-bond compounds and $\mathrm{N}$ heterocycles. ${ }^{[16,19-22]}$ The different reactivities and properties of phosphine-boranes, phosphino-boranes and phosphino-boronate esters depends on the coordination number of the phosphorus and boron atoms as well as the presence or absence of the phosphorus lone pair and boron vacant $2 p$ orbital.

Increasing the coordination number of the phosphorus not only from three to four, but also to five alternatively masks the lone pair of the phosphorus atom. Phosphoranes, pentacoordinated organophosphorus compounds, have been known to show different reactivities, such as ligand coupling, ${ }^{[23]}$ from those of phosphines and phosphonium salts. ${ }^{[24-26]}$ Thus, incorporation of a pentacoordinated phosphorus atom for P-B bonded compounds could show unique properties and reactivities. Only a few examples of compounds bearing a P-B bond between pentacoordinated phosphorus-tetracoordinated boron atoms have appeared in either theoretical calculations, or as a reaction intermediate in formation of a possible reduction product. ${ }^{[9,26-32]}$ Although these compounds have promising application in the construction of new compounds containing phosphorus-boron frameworks, formation of a stable P-B bonded compound with a pentacoordinated phosphorus atom is difficult. A boron atom of low electronegativity is insufficient for the electron withdrawal that is required to stabilise the pentacoordinated phosphorus atom.

However, we recently reported the first examples of a stable pentacoordinated phosphorus-tetracoordinated boron bonded compound by isolating phosphoranyl-trihydroborates 1a $(\mathrm{M}=$ $\mathrm{K} \cdot 18$-crown-6) and $\mathbf{1 b}\left[\mathrm{M}=(n-\mathrm{Bu})_{4} \mathrm{~N}\right]($ Chart 1$) \cdot{ }^{[33]} \mathrm{A}$ pair of the strongly electron-withdrawing $\mathrm{C}, \mathrm{O}$-bidentate ligand (-[2$\left.\left.\mathrm{C}_{6} \mathrm{H}_{4} \mathrm{C}\left(\mathrm{CF}_{3}\right)_{2} \mathrm{O}\right]-\right)^{[34,35]}$ around the phosphorus atom, which has been used to stabilise many other anionic hypercoordinated phosphorus compounds, ${ }^{[36-40]}$ contributes to the withdrawal of electrons through the phosphorus atom for the stabilisation of phosphoranyl-trihydroborates $\mathbf{1 a , b}$. Here we report the full investigation into pentacoordinated phosphorus-tetracoordinated boron bonded compounds. A new phosphoranyl-borate was synthesised, fully characterised and its structure and reactivity explored. In addition, the reactivity of $\mathbf{1}$ was further explored, 
which showed it could act as a monohydroboration reagent with good regioselectivity.

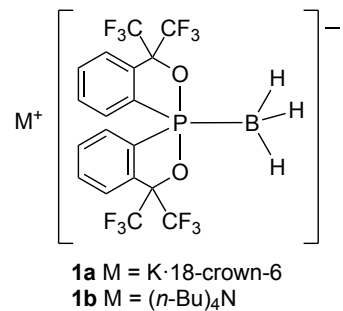

Chart 1. Phosphoranyl-trihydroborates $\mathbf{1 a}$ and $\mathbf{1 b}$.

\section{Results and Discussion}

\section{Synthesis}

Phosphoranyl-trihydroborates $\mathbf{1} \mathbf{a}, \mathbf{b}$ were synthesised by reacting phosphoranide ${ }^{[41-43]} \mathbf{2 a}, \mathbf{b}$, respectively, with $\mathrm{BH}_{3} \cdot \mathrm{THF}$ in THF and were obtained in good yields (Scheme 1). Further investigation of the reactivity of phosphoranide 2 and its ability to create a P-B bond was undertaken through a borane reagent screen. Reaction of 2 with boron reagents such as $\mathrm{BPh}_{3}, \mathrm{BEt}_{3}, \mathrm{~B}(\mathrm{OMe})_{3}, 9$ borabicyclo[3.3.1]nonane, catecholborane, bis(catecholato)diboron, pinacolborane, bis(pinacolato)diboron and methoxypinacolborane gave no reaction and thus failed to form a $\mathrm{P}-\mathrm{B}$ bond. The failure of these reagents to form a $\mathrm{P}-\mathrm{B}$ bond with $\mathbf{2}$, in contrast with the formation of $\mathbf{1 a , b}$, is most likely due to the decreased Lewis acidity of their boron atom, which prevents their reaction with the sterically hindered tetracoordinated phosphorus of 2.

Phosphoranide 2 reacted with $B$-chlorocatecholborane, but gave a mixture of hydrophosphorane ${ }^{[42,43]}$ and potassium arylspiroborate ester, 18-crown-6 $\left(\mathrm{K}\left[\mathrm{B}\left(\mathrm{C}_{6} \mathrm{H}_{4} \mathrm{O}_{2}\right)_{2}\right] \cdot \mathrm{C}_{12} \mathrm{H}_{24} \mathrm{O}_{6}\right)^{[44,45]}$ without formation of any $\mathrm{P}-\mathrm{B}$ bonded product (See Supporting Information, Figures S1-S3). Moreover, reaction with $\mathrm{BX}_{3}(\mathrm{X}=\mathrm{Cl}$ and $F$ ), gave a mixture of an unstable $P-B$ bonded compound $(\delta P$ $=66.3 \mathrm{ppm}, J_{\mathrm{BP}}=165 \mathrm{~Hz} ; \delta_{\mathrm{B}}=2.2 \mathrm{ppm}, J_{\mathrm{BP}}=163 \mathrm{~Hz}$ ), chlorophosphorane ${ }^{[46]}$ and hydrophosphorane for $\mathrm{BCl}_{3}$ and hydrophosphorane for $\mathrm{BF}_{3} \cdot \mathrm{OEt}_{2}$ (See Supporting Information, Figures S4-S9). The P-B bonded product was not isolated because of its instability.

Lastly, the reagent screen revealed that phosphoranides $2 \mathrm{a}$ and $2 b$ could react with $\mathrm{B}\left(\mathrm{C}_{6} \mathrm{~F}_{5}\right)_{3}$ to give phosphoranyl-triarylborates 3a $\left(\mathrm{M}=\mathrm{K} \cdot 18\right.$-crown-6) and $\mathbf{3 b}\left[\mathrm{M}=(n-\mathrm{Bu})_{4} \mathrm{~N}\right]$, respectively, in good yields. Formation of phosphoranyl-borates $\mathbf{3 a}$ and $\mathbf{3 b}$ was unexpected as the screening of the other reagents, such as $\mathrm{BPh}_{3}$, indicated that the combination of the bulky phosphoranide anion and $\mathrm{B}\left(\mathrm{C}_{6} \mathrm{~F}_{5}\right)_{3}$ would form a frustrated Lewis pair rather than $\mathrm{P}-\mathrm{B}$ bond formation. ${ }^{[47,48]}$ Although the increase of the coordination number may increase the steric hindrance around the phosphorus, the appropriate combination of a borane reagent with the phosphoranide, which is a strong base, can form the Lewis adduct in this case. Thus, the strong Lewis acids of $\mathrm{BH}_{3}$ and $\mathrm{B}\left(\mathrm{C}_{6} \mathrm{~F}_{5}\right)_{3}$ are important in $\mathrm{P}-\mathrm{B}$ bond formation despite the increase of the coordination number. Sufficient electron withdrawing ability of both the phosphorus and boron moieties could contribute to stabilising the pentacoordinated state of the phosphorus atom of phosphoranyl-borates $\mathbf{1} \mathbf{a}, \mathbf{b}$ and $\mathbf{3 a} \mathbf{a}, \mathbf{b}$.

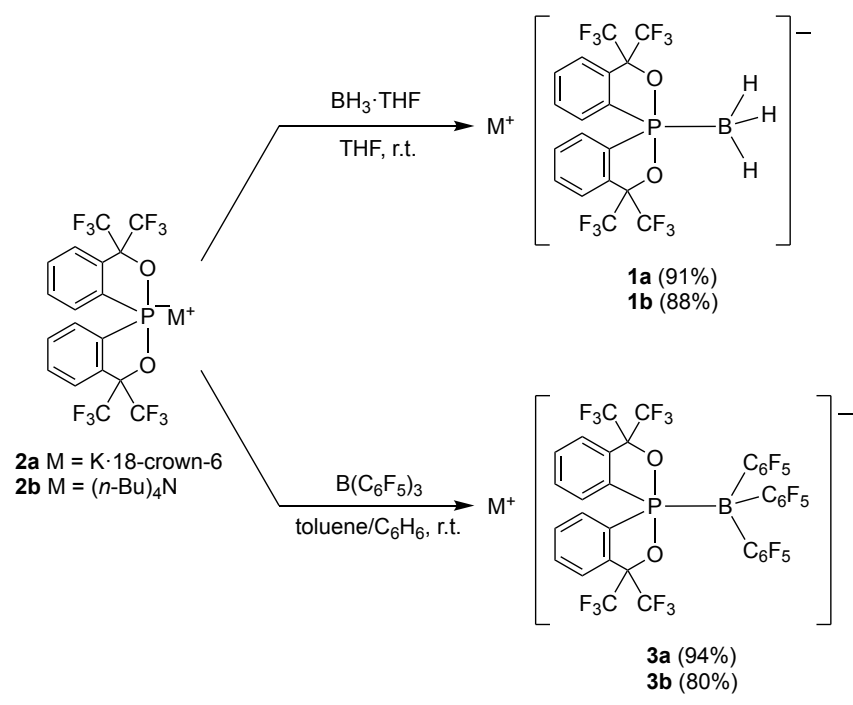

Scheme 1. Synthesis of phosphoranyl-borates $\mathbf{1} \mathbf{a}, \mathbf{b}$ and $\mathbf{3 a} \mathbf{a} \mathbf{b}$

Phosphoranyl-trihydroborates $\mathbf{1 a}, \mathbf{b}$ and phosphoranyltriarylborates $\mathbf{3 a}, \mathbf{b}$ were isolated as colourless crystals. All the compounds were fully characterised by X-ray crystallographic analysis, NMR spectroscopy, mass spectrometry and elemental analysis.

\section{X-ray Crystallographic Analysis}

The crystal structure of $\mathbf{1 b}$ has been previously reported ${ }^{[33]}$, and the structure of $\mathbf{1 a}$ and $\mathbf{3} \mathbf{a}, \mathbf{b}$ are now revealed. The X-ray crystallographic analysis of $1 \mathrm{a}$ showed the existence of a P-B bond featuring $\mathrm{P} 1$ and $\mathrm{B} 1$ atoms of trigonal bipyramidal and tetrahedral geometries, respectively (Figure 1a). This structure of $\mathbf{1 a}$ is very similar to that of $\mathbf{1 b}$, except an interaction between the potassium ion, $\mathrm{K} 1$, and the hydrogens around the boron atom at an average distance of $2.8 \AA$. An interaction with the countercation was not observed for the tetrabutylammonium salt (Figure $1 \mathrm{~b})$ and has negligible effect on the structure as the $P-B$ bond of 1a [1.942(2) $\AA$ ] was similar to that of 1b [1.959(3) $\AA$ (1.937(3) $\AA$ for the independent molecule in the unit cell)]. Moreover, one of $\mathrm{B}-\mathrm{H}$ bonds in both $1 \mathrm{a}$ and $\mathbf{1 b}$ is eclipsed with one of the $\mathrm{P}-\mathrm{O}$ bonds with torsion angle of $8^{\circ}$, regardless of the interaction. 
(a)

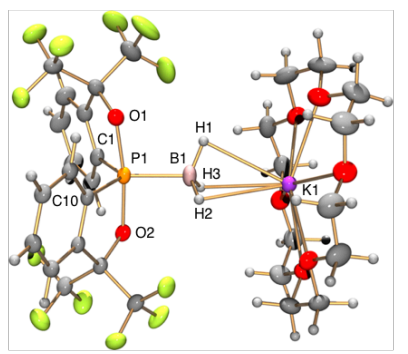

(b)

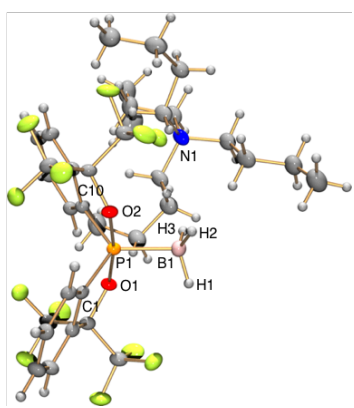

Figure 1. ORTEP drawings of $\mathbf{1 a}(a)$ and $\mathbf{1 b}(\mathrm{b})$ with thermal ellipsoids at the $50 \%$ probability level. One of two independent molecules in the unit cell of $1 \mathbf{b}$ is shown. A molecule of benzene was omitted from the structure of $\mathbf{1 a}$ and $\mathbf{1} \mathbf{b}$ for clarity. Selected bond lengths $(\AA)$ and bond angles (deg): 1a; P1-B1 1.942(2), P1-O1 1.817(1), P1-O2 1.830(1); O1-P1-O2 171.53(5), O1-P1-B1 95.97(8), O2-P1-B1 92.49(8). 1b; P1-B1 1.959(3), P1-O1 1.820(2), P1-O2 1.825(2); O1-P1-O2 171.43(8), O1-P1-B1 95.34(11), O2-P1-B1 93.23(11).

The crystal structures of $\mathbf{3 a}$ and $\mathbf{3 b}$ are shown in Figure 2. Both complexes $\mathbf{3} \mathbf{a}$ and $\mathbf{3} \mathbf{b}$ feature a P-B bond, in which the phosphorus and boron atoms are penta- and tetracoordinated, respectively. On one hand, the anion of $3 a$ interacts with the potassium ion, $\mathrm{K} 1$, to form an ion pair with a $p$-fluorine $(\mathrm{F} 19)$ atom of a $\mathrm{C}_{6} \mathrm{~F}_{5}$ ring with a distance of 2.908(2) $\AA$ (3.040(2) $\AA$ for the molecule in the unit cell) (Figure 2a). On the other hand, the anion of $\mathbf{3 b}$ shows no contact with the tetrabutylammonium ion (Figure $2 b)$. The P1 atom is bonded to one boron and two carbon atoms in the equatorial positions, and two oxygens in the apical positions The phosphorus coordination polyhedral for $\mathbf{3 b}$ is described as a distorted trigonal bipyramid [O-P-O angle, $172.50(5)^{\circ}$ ], whilst the boron coordination polyhedral is described as a distorted tetrahedral [C-B-C av. 110.0(4) A]. The P-B bond length of $3 \mathbf{b}$ $[2.075(3) \AA]$ is shorter to that of $\mathrm{Ph}_{3} \mathrm{P}-\mathrm{B}\left(\mathrm{C}_{6} \mathrm{~F}_{5}\right)_{3}[2.180(6) \AA],{ }^{[49]}$ showing that the pentacoordinated state of the phosphorus could shorten the $\mathrm{P}-\mathrm{B}$ bond length. Conversely, it is considerably longer than that of $1 \mathbf{b}[1.959(3) \AA],{ }^{[33]}$ reflecting the increased bulk around the P-B bond. The P-O bond lengths [1.806(1)-1.807(1) $\AA]$ are considerably longer than those found in the hydroxyphosphorane $[1.7059(18)-1.7421(18) \AA],^{[50]}$ but similar to those of $1 \mathbf{b}$ $[1.8102(17)-1.8406(17) \quad \AA]$ and a phosphoranide-palladium complex, $\quad\left[\left(2-\mathrm{C}_{6} \mathrm{H}_{4} \mathrm{C}\left(\mathrm{CF}_{3}\right)_{2} \mathrm{O}\right)_{2} \mathrm{P}-\mathrm{Pd}(\mathrm{PhCHO})(\mathrm{dppe})\right]\left(\mathrm{SbF}_{6}\right)$, [av. 1.780(3), 1.851(3) Å. ${ }^{\left[{ }^{[1]}\right.}$ The long $\mathrm{P}-\mathrm{O}$ bond lengths indicated localisation of substantially negative charges on the oxygen atoms and weakening of the polar $\mathrm{P}-\mathrm{O}$ bonds.

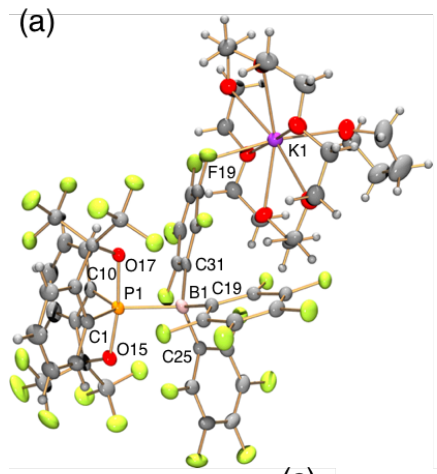

(b)

(c)
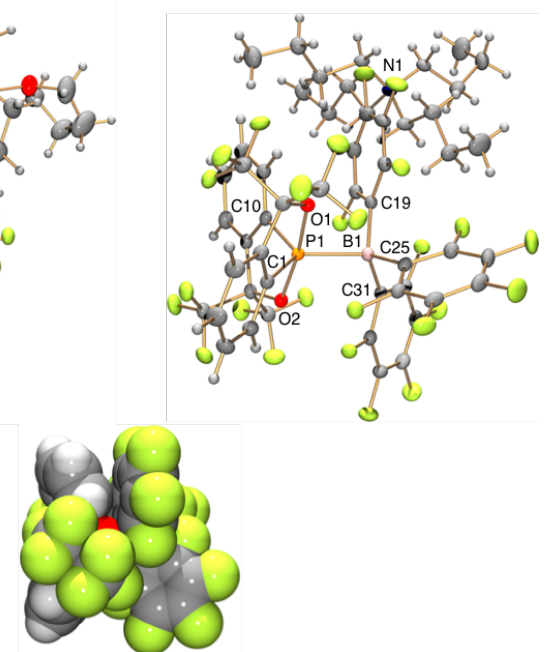

Figure 2. ORTEP drawings of $\mathbf{3 a}(\mathbf{a})$ and $\mathbf{3 b}(\mathrm{b})$ with thermal ellipsoids at the $50 \%$ probability level. (c) Space-filling model view of the anion of $\mathbf{3 b}$. Selected bond lengths $(\AA)$ and bond angles (deg): 3a; P1-B1 2.075(3), P1-O15 1.781(2), P1-O17 1.812(2); O15-P1-O17 171.71(9), O15-P1-B1 97.9(1), O17-P1-B1 90.3(1). 3b; P1-B1 2.093(1), P1-O1 1.8071(9), P1-O2 1.8064(9); O1-P1O2 172.50(4), O1-P1-B1 89.38(5), O2-P1-B1 98.11(5).

The crystal structures of $\mathbf{3 a}$ and $\mathbf{3 b}$ were found to be in the $O$ apical pseudorotamer. This pseudorotamer is thought to be more stable and thus favoured due to high electronegativity of oxygen and the large steric bulk around the P-B bond, which can be observed in the space-filling model of the anion of $\mathbf{3 b}$ (Figure $2 \mathrm{c}$ ). This $B$-equatorial conformation and steric bulk led to one of the $\mathrm{C}_{6} \mathrm{~F}_{5}$ rings within close proximity to an apical oxygen. As a result, one of the quaternary carbons (C31) of the $\mathrm{C}_{6} \mathrm{~F}_{5}$ rings is eclipsed with the apical oxygen $(\mathrm{O} 2)$ bonded to the phosphorus with a torsion angle of $0.4^{\circ}$. This eclipsed conformation is also found as a key feature in the crystal structure of $\mathbf{3} \mathbf{a}$.

\section{NMR Spectroscopy}

The structure of $\mathbf{3}$ in solution state was consistent with its crystal structures. The ${ }^{1} \mathrm{H}$ NMR spectra of $\mathbf{3 b}$ in THF- $d_{8}$ showed the ortho proton signal of the benzene ring of the ligand in a low-field region of $8.71 \mathrm{ppm}$. This reflects the proximity and deshielding effect of the apical bond of the trigonal bipyramidal structure, indicating the C-equatorial conformation. ${ }^{[11]}$ The ${ }^{19} \mathrm{~F}$ NMR showed three quartets and one multiplet peaks for the $\mathrm{CF}_{3}$ groups on the two sets of bidentate ligands. This result shows that $\mathbf{3 a}$ is predominately the $\mathrm{O}$-apical pseudorotamer in solution state, as found in the crystal structure, due to the lack of pseudorotation of the bidentate ligand groups around the pentacoordinated phosphorus atom. ${ }^{[52]}$ This is thought to be due to the large equatorial bulk of the $\mathrm{B}\left(\mathrm{C}_{6} \mathrm{~F}_{5}\right)_{3}$ moiety, which hinders rotation of the bidentate ligands. 
The lack of pseudorotation was also observed with $1 \mathrm{a}$, even when analysed at high temperatures $\left(+30{ }^{\circ} \mathrm{C}\right.$ to $+60{ }^{\circ} \mathrm{C}$ ) (See Supporting Information, Figure S38), which showed a pair of quartets for the $\mathrm{CF}_{3}$ groups in the ${ }^{19} \mathrm{~F}$ NMR spectra. This was easily seen in the variable temperature ${ }^{19} \mathrm{~F}$ NMR analysis, in which the two quartet peaks for each of the $\mathrm{CF}_{3}$ groups remained unchanged until $+60^{\circ} \mathrm{C}$. At lower temperatures $\left(-45\right.$ to $\left.-80^{\circ} \mathrm{C}\right)$, only a little peak broadening, which is due to slow rotation of the $\mathrm{CF}_{3}$ groups around the adjacent carbon at low temperatures, was observed (See Supporting Information, Figure S39).

The non-decoupled ${ }^{11} \mathrm{~B}$ NMR spectrum gave a doublet peak at $\delta_{\mathrm{B}}$ $=-10.3 \mathrm{ppm}$ with a coupling to the phosphorus atom of ${ }^{1} \mathrm{~J}_{\mathrm{BP}}=156$ $\mathrm{Hz}$. The chemical shift of the doublet peak is in an upfield shift from that of $\mathrm{Ph}_{3} \mathrm{P}-\mathrm{B}\left(\mathrm{C}_{6} \mathrm{~F}_{5}\right)_{3}(-2.5 \mathrm{ppm}) .{ }^{[49]}$ The coupling constant ${ }^{1} J_{\mathrm{BP}}$ of $\mathbf{3 b}$ is larger than that of $\mathrm{Ph}_{3} \mathrm{P}-\mathrm{B}\left(\mathrm{C}_{6} \mathrm{~F}_{5}\right)_{3}\left({ }^{1} \mathrm{~J}_{\mathrm{BP}}=110 \mathrm{~Hz}\right)$ and 1a $\left({ }^{1} J_{B P}=69 \mathrm{~Hz}\right)^{[33]}$, reflecting the large s-character of the $P-B$ bond featuring the trigonal bipyramidal phosphorus. ${ }^{[53]}$ The proton-decoupled ${ }^{31} \mathrm{P}$ NMR spectrum of $\mathbf{3 b}$ showed a broad quartet at $\delta \mathrm{p}-15.6 \mathrm{ppm}$, which is in a similar region compared to that of hydroxyphosphorane, $\left[\mathrm{C}_{6} \mathrm{H}_{4}-2-\mathrm{C}\left(\mathrm{CF}_{3}\right)_{2} \mathrm{O}_{2} \mathrm{POH},(\delta \mathrm{P}-17.6\right.$ $\mathrm{ppm})^{[36]}$ and chlorophosphorane, $\left[\mathrm{C}_{6} \mathrm{H}_{4}-2-\mathrm{C}\left(\mathrm{CF}_{3}\right)_{2} \mathrm{O}\right]_{2} \mathrm{PCl},(\delta \mathrm{P}-7.6$ ppm). ${ }^{[46]}$ However, it is somewhat a high-field shift to that of $\mathrm{Ph}_{3} \mathrm{P}$ $\mathrm{B}\left(\mathrm{C}_{6} \mathrm{~F}_{5}\right)_{3} \quad\left(\delta_{\mathrm{P}}-2.5 \mathrm{ppm}\right),{ }^{[49]}$ reflecting the pentacoordinated phosphorus state.

\section{DFT Calculations}

The density functional theory (DFT) calculations for the anion of 3 , at B3PW91/6-31+G(d,p) level, were conducted to evaluate the bond properties and molecular orbitals. The heterolytic bond dissociation energy of the P-B bond of anion $\mathbf{3}$ was calculated to be $18.1 \mathrm{kcal} \mathrm{mol}{ }^{-1}$, which is almost the same as that of $\mathrm{Me}_{3} \mathrm{P}$ $\mathrm{B}\left(\mathrm{C}_{6} \mathrm{~F}_{5}\right)_{3}\left(17.8 \mathrm{kcal} \mathrm{mol}^{-1}\right)$, but smaller than that of the anion of 1 $\left(33.8 \mathrm{kcal} \mathrm{mol}^{-1}\right) \cdot{ }^{[33]}$ Moreover, it was found to be smaller than the homolytic bond dissociation energy of the P-B bond (32.1 kcal $\mathrm{mol}^{-1}$ ), suggesting preference of heterolysis of the $\mathrm{P}-\mathrm{B}$ bond in 3 . (a)

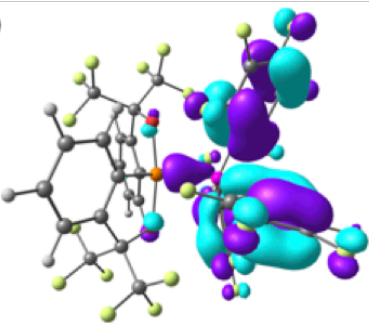

(b)

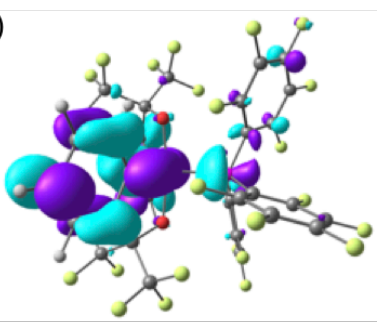

Figure 3. The HOMO $(-4.51 \mathrm{eV} ; \mathrm{a})$ and LUMO $(+0.70 \mathrm{eV} ; \mathrm{b})$ of the anion of 3 . The natural charges of the phosphorus $(+1.64)$ and boron $(+0.19)$ atoms of 3, which were obtained by natural population analysis, ${ }^{[54]}$ indicate a highly polarised $\mathrm{P}-\mathrm{B}$ bond character. The natural charges of the oxygen $(-0.83)$ and carbon $(-0.35$ and -0.34$)$ atoms suggest that the $\mathrm{P}-\mathrm{O}$ and $\mathrm{P}-\mathrm{C}$ bonds are more polarised than the P-B bond. All three carbon atoms on the boron show negative natural charges $(-0.35,-0.36$ and -0.38$)$ as a result of their bonding to a less electronegative boron atom.

The HOMO is localised on the $\sigma$ orbital of the P-B bond and $\pi$ orbitals of the $\mathrm{C}_{6} \mathrm{~F}_{5}$ aromatic rings (Figure $3 a$ ), whilst the LUMO is localised mainly on the $\pi^{*}$ orbitals of the aromatic rings of the bidentate ligand (Figure $3 \mathrm{~b}$ ). The contribution of the $\sigma$ orbital of the $\mathrm{P}-\mathrm{B}$ bond is small in the frontier orbitals, corresponding to the stability of compounds $\mathbf{3 a , b}$.

Anions 1 and $\mathbf{3}$ were further investigated by Bader's Atoms in Molecules (AIM) analysis ${ }^{[55]}$ by mapping the topology of electron density $(\rho(r))$. The bond critical points (BCPs) for the P-B bond of anion 1 gave $\rho(r)$ and $-\nabla^{2} \rho(r)$ values of $0.1087 \mathrm{e} / \mathrm{bohr}^{3}$ and 0.0151 e/bohr ${ }^{5}$, respectively, confirming its ionic character. However, analysis of anion 3 showed that $\rho(r)$ was $0.0956 \mathrm{e} / \mathrm{bohr}^{3}$ and $\nabla^{2} \rho(r)-0.151$ e/bohr $r^{5}$, indicating the bond is of more covalent character. The difference between the two bonds reflects the stronger electron-withdrawing ability of the $\mathrm{C}_{6} \mathrm{~F}_{5}$ groups on the boron atom of $\mathbf{3}$ than the hydrogens on the boron atom of $\mathbf{1}$, and suggests that the $B\left(C_{6} F_{5}\right)_{3}$ moiety helps to decrease polarisation of the $\mathrm{P}-\mathrm{B}$ bond. Interestingly, bond paths were found between fluorine atoms of each $\mathrm{CF}_{3}$ group with hydrogens on the boron for 1 (See Supporting Information, Figure S41). In addition, bond paths were also observed for anion 3 between some fluorine atoms of the $\mathrm{CF}_{3}$ groups and carbon atoms of $\mathrm{C}_{6} \mathrm{~F}_{5}$ rings. These interactions, each of which is very weak, could help the previously mentioned eclipsed feature of a $\mathrm{P}-\mathrm{O}$ bond with a $\mathrm{B}-\mathrm{H}$ or $\mathrm{B}-\mathrm{C}$ bond observed in the X-ray crystal structure.

\section{Hydride Abstraction}

It was found that a single hydride abstraction of phosphoranyltrihydroborate 1a with tropylium tetrafluoroborate would lead to THF stabilised intermediate 4 (Scheme 2), which was confirmed by trapping with pyridine. ${ }^{[33]}$ Additionally, it was discovered that intermediate 4 could rearrange to form fused bicyclic compound 5 through a unique double ring expansion rearrangement reaction after solvent exchange from $\mathrm{THF}$ to $\mathrm{Et}_{2} \mathrm{O}$. It is now revealed that direct access to $\mathbf{5}$ can be achieved in good yield by treatment of 1a with methyl triflate in toluene at room temperature. The lack of a coordination solvent allows the rearrangement to occur spontaneously upon hydride abstraction accompanied by the reduction of methyl triflate. It should be mentioned that the coordinatively stabilised phosphine is readily accessible starting from the corresponding phosphorane. ${ }^{[56]}$ 


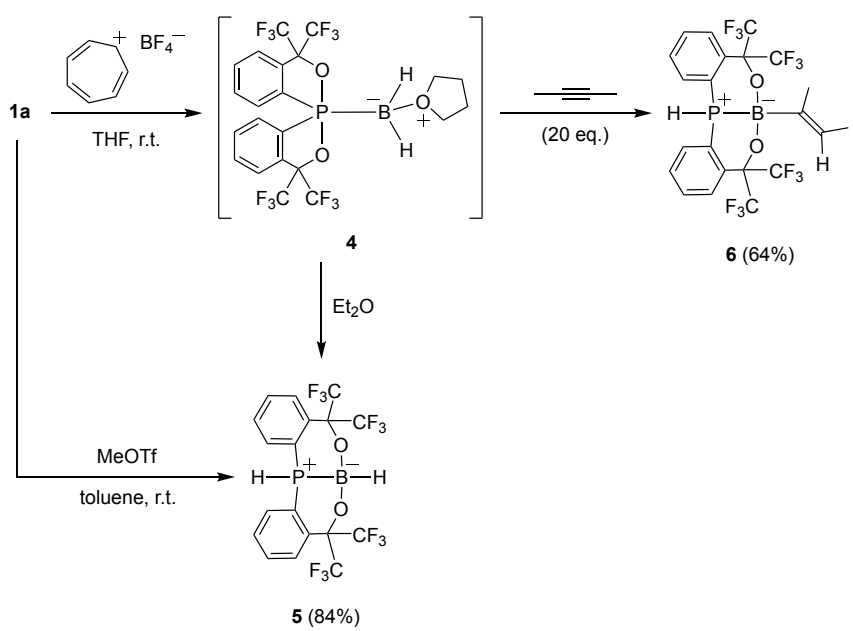

Scheme 2. Reactions of phosphoranyl-borate 1a.

\section{Hydroboration Reactivity}

Intermediate 4 was also shown to effectively mono-hydroborate 2-butyne, even though a large excess was used, to give bicyclic compound 6 (Scheme 2). The X-ray crystal structure of 6 showed a similar structure to the previously synthesised bicyclic compound 5 (Figure 4). However, instead of a H-P-B-H linkage, a $\mathrm{H}-\mathrm{P}-\mathrm{B}-($ but-2-ene) linkage with a synclinal conformation [torsion angle, $42.3^{\circ}$ ] was observed. The 2-butene moiety was also found to be in a (Z)-conformation. The P-B bond of $6[\mathrm{P}-\mathrm{B}$ 2.004(5) $\AA$ ] was slightly longer than 5 [P-B 1.972(3) $\AA$ ], reflecting the decrease in electron density of the substituted boron atom. (a)

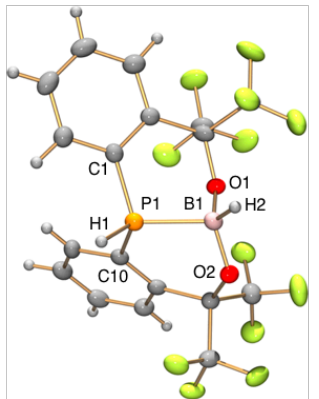

(b)

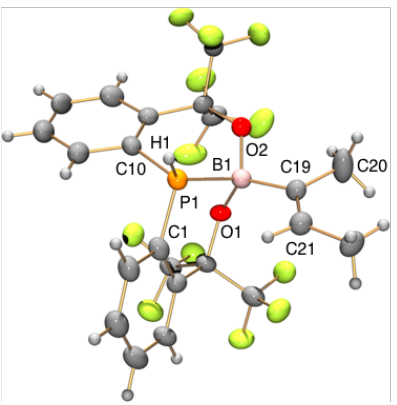

Figure 4. ORTEP drawings of $\mathbf{5}$ (a) and $\mathbf{6}$ (b) with thermal ellipsoids at the $50 \%$ probability level. Selected bond lengths $(\AA)$, bond angles (deg) and torsion angles (deg): 5; P1-B1 1.971(3), P1-H1 1.33(2), B1-O1 1.469(3), B1-O2 1.441(3), B1-H2 1.09(2); C1-P1-H1 105(1), C10-P1-H1 107(1), O1-B1H2 116(1), O2-B1-H2 111(1); H1-P1-B1-H2 -47(2). 6; P1-B1 2.004(5), P1H1 1.34(6), B1-O1 1.477(5), B1-O2 1.466(5); C1-P1-H1 105(2), C10-P1H1 104(2), O1-B1-C19 121.4(3), O2-B1-C19 109.9(3); H1-P1-B1-C19 42(3).

The mechanism for the formation of $\mathbf{6}$ from the reaction of $\mathbf{4}$ and 2-butyne is thought to first undergo a regular hydroboration reaction to give 7 (Scheme 3). Then, an oxygen shift occurs from the phosphorus to the boron atom to give intermediate $\mathbf{8}$, which is quickly followed by a hydride shift from the boron to the phosphorus atom to give 9. Finally, a second oxygen shift from the phosphorus to the boron atom gives the bicyclic ring structure of 6. It was observed that only mono-hydroboration occurred even though there is a second hydrogen atom on the borane moiety of 4 and a large excess of the substrate was used. This result shows the rearrangement to give the fused bicyclic product $\mathbf{6}$, which is accompanied with a double ring expansion, is faster than secondary hydroboration.

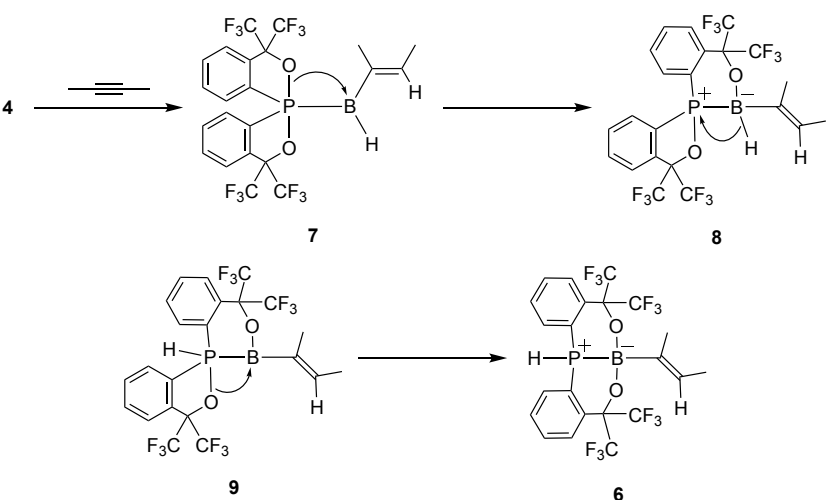

Scheme 3. Proposed reaction mechanism for the formation of $\mathbf{6}$ from 4 and 2 butyne.

Conversion of $\mathbf{6}$ to the boronic acid ester as an isolable form was thought to be a promising strategy because some boronic acid esters have been utilised for Suzuki-Miyaura cross-coupling reactions. ${ }^{[57,58]}$ Treatment of 6 with $\mathrm{H}_{2} \mathrm{O}$ was found to cleave its $\mathrm{P}-$ $B$ bond to give $(Z)-2$-butene boronic acid $\left(\delta_{B}=+28.2 p p m\right)$, which matched the literature value. ${ }^{[59]}$ The boronic acid was successfully converted to the corresponding $\mathrm{N}$-methyliminodiacetic acid ester (MIDA) to give 10 , which was isolated in $60 \%$ yield after silica gel column chromatography (Table 1, entry 1 ). To further explore the hydroboration reactivity of $\mathbf{4}$, a study was undertaken on various alkynes and alkenes. It was found to effectively hydroborate terminal alkynes, 1-heptyne and ethynylbenzene, to give the corresponding MIDA esters 11 and 12 in yields of 68 and $62 \%$, respectively, after purification (entries 2-3). The hydroboration regioselectivity of $\mathbf{4}$ for 1-heptyne and ethynylbenzene was predominately for the terminal carbon, but $30 \%$ and $40 \%$ of the two-isomer was obtained for each alkyne, respectively. When 4 was reacted with terminal alkenes, 1-hexene and styrene, the corresponding MIDA ester products 13 and 14 were isolated in slightly lower yields of 49 and $38 \%$, respectively, even after longer reaction time (entries 4-5). These results show that $\mathbf{4}$ has higher reactivity towards alkynes over alkenes. Although the overall yield of the hydroboration was lower for alkenes, the regioselectivity was improved giving $75 \%$ and $90 \%$ of the 1 -isomer for 1 -hexene and 1-styrene, respectively. Hydroboration with 2,3-dimethyl-2butene, an internal alkene, was also undertaken, but unfortunately, only $\sim 5 \%$ of hydroborated bicyclic P-B 
intermediate could be observed by ${ }^{19} \mathrm{~F}$ NMR spectroscopy after 72 hours (entry 6).

Table 1. Hydroboration of alkynes and alkenes using intermediate 4.

Entry Substrate $\begin{gathered}\text { Reaction } \\ \text { Time }\end{gathered}$ Product(s)

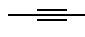

$24 \mathrm{~h}$

$\eta=<^{\mathrm{H}}$

10

$24 \mathrm{~h}$

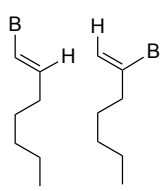

$7: 3$

$68 \%[\mathrm{~b}, \mathrm{c}]$

11a 11b<smiles>C#Cc1ccccc1</smiles>

$24 \mathrm{~h}$

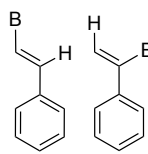

$3: 2$

$62 \%$

12a $12 b$

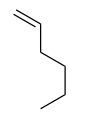

$48 \mathrm{~h}$

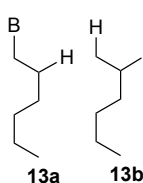

$48 \mathrm{~h}$

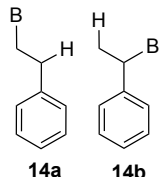

$14 a \quad 14 b$
6

$72 \mathrm{~h}$

$<5 \%$ [d] hydrophosphorane in solution over time. Considering that 1,3dimethylimidazol-2-ylidene borane shows similar hydroboration reactivity, ${ }^{[69,70]}$ the effect of the phosphoranide on the reactivity of the borane moiety is comparable to that of a $\mathrm{N}$-heterocyclic carbene $(\mathrm{NHC}) \cdot{ }^{[71]}$ It should be noted that $\mathrm{BH}_{3} \cdot \mathrm{THF}$, thexylborane and $\mathrm{NHC}-\mathrm{BH}_{3}$ compounds can undergo secondary hydroboration, which highlights the advantages of this reported monohydroboration strategy.

\section{Stability}

Phosphoranyl-trihydroborates $\mathbf{1 a}, \mathbf{b}$ and phosphoranyltriarylborates $\mathbf{3} \mathbf{a}, \mathbf{b}$ are thermally stable at room temperature and could be handled in air without precautions. It makes remarkable contrast with the previously reported intermediary generated pentacoordinated phosphorus-boron bonded species. ${ }^{[30-32]}$ The impressive stability of these new compounds is ascribed to the stabilising effect of the electron-withdrawing bidentate ligand on the phosphorus atom. Surprisingly, 3a showed persistence towards base hydrolysis and alcoholysis even though it possesses a long $\mathrm{P}-\mathrm{B}$ bond. It was also stable towards diisopropyl- and diethylamine, which are known to cleave P-B bonds of phosphine-boranes. ${ }^{[5-8]}$ However, 3a was found to have good stability towards acid, since treatment with $1 \mathrm{M}$ hydrochloric acid would give hydrophosphorane ${ }^{[42,43]}$, quantitatively, after 4 days at room temperature. This is different to $1 \mathrm{a}$ as it reacted with $1 \mathrm{M} \mathrm{HCl}$ instantaneously due to its hydride reactivity. Further studies of $\mathbf{3 a}$ with tetrabutylammonium fluoride, methyl iodide and methyl triflate gave no reaction. The stability of $3 a$ could be explained by the large bulk around the P-B bond (Figure $2 \mathrm{c}$ ).

\section{Conclusion}

In summary, we isolated and explored the reactivities of two pentacoordinated phosphorus-tetracoordinated boron bonded compounds. This study revealed that a strong Lewis acidic boron reagent and electron-withdrawing ligand system around the pentacoordinated phosphorus was required to form the $\mathrm{P}-\mathrm{B}$ bond and stabilise the phosphoranyl-borates. Compound 1, a phosphoranyl-trihydroborate, gave phosphoranyl-borane intermediate $\mathbf{4}$ upon a single hydride abstraction. This compound could undergo a unique rearrangement reaction, that involved a two-fold ring expansion, to give $\mathbf{5}$ or it could act as a monohydroboration reagent. The hydroboration reactivity of $\mathbf{4}$ was found to be more reactive towards alkynes over alkenes with good to moderate regioselectivity towards the terminal carbon. Compound 3, a phosphoranyl-triarylborate, was found to have a long P-B bond and a vastly different reactivity to 1 as it was highly stable towards acids and bases. This was due to the large bulk 
around the $\mathrm{P}-\mathrm{B}$ bond as shown in the crystal structure. The potential impact of these compounds for $\mathrm{P}-\mathrm{B}$ bond-containing polymers are promising and further studies are currently underway.

\section{Experimental Section}

\section{General Remarks}

Solvents were pre-dried and purified before use by an MBRAUN MB-SPS solvent purification system and further dried with molecular sieves $4 \AA$. All reactions were carried out under an argon atmosphere. All NMR spectra were measured with Bruker AV300 spectrometer. Solvents peaks were used as an internal standard for the ${ }^{1} \mathrm{H}$ NMR $(300 \mathrm{MHz})$ and ${ }^{13} \mathrm{C}$ NMR $(75 \mathrm{MHz})$ spectra. $\mathrm{F}_{3} \mathrm{~B} \cdot \mathrm{OEt} 2, \mathrm{CFCl}_{3}$ and $\mathrm{H}_{3} \mathrm{PO}_{4}$ were used as external standards for the ${ }^{11} \mathrm{~B}$ NMR (96.3 MHz), ${ }^{19} \mathrm{~F}$ NMR (282 MHz) and ${ }^{31} \mathrm{P}$ NMR $(121 \mathrm{MHz})$ spectra, respectively. The ESI-mass spectral data were obtained on Thermo Scientific Exactive mass spectrometer. Melting points were recorded with a Yanaco MP500D micro melting point apparatus and were uncorrected. Elemental analysis was performed by the Microanalytical Laboratory from the Department of Chemistry, Faculty of Science, The University of Tokyo. Phosphoranides were prepared from hydrophosphorane, $\left[\mathrm{C}_{6} \mathrm{H}_{4}-2-\mathrm{C}\left(\mathrm{CF}_{3}\right)_{2} \mathrm{O}_{2} \mathrm{PH}\right.$, according to the procedure in the literature. ${ }^{[42,43]}$ Phosphoranyl-trihydroborates were prepared according to our previous reported studies. ${ }^{[3]}$ Tris(pentafluorophenyl)borane and $\mathrm{BH}_{3}$ THF were purchased from TCl Chemicals and Sigma-Aldrich, respectively, and used without further purification. All alkynes and alkenes used in hydroboration reactions were freshly distilled prior to use except for 2-butyne, which was passed through a bed of basic alumina. All isomer ratios for hydroboration reactions were determined by ${ }^{1} \mathrm{H}$ NMR spectroscopy.

\section{Synthesis of Potassium Phosphoranyl-borate (3a)}

To a suspension of potassium phosphoranide $2 \mathrm{a}(0.50 \mathrm{~g}, 0.61$ $\mathrm{mmol})$ in toluene $(10 \mathrm{~mL})$ was added a solution of $\mathrm{B}\left(\mathrm{C}_{6} \mathrm{~F}_{5}\right)_{3}(0.31$ $\mathrm{g}, 0.61 \mathrm{mmol})$ in toluene $(10 \mathrm{~mL})$ and the mixture was stirred at room temperature for $1 \mathrm{~h}$. The reaction mixture was concentrated under reduced pressure and the resulting solid was dissolved in THF, filtered through a pad of Celite and concentrated under reduced pressure to give a solid. The solid was recrystallised from $\mathrm{THF} /$ hexanes to give a 1:1 solvate of potassium phosphoranylborate 18-crown-6 3a with a molecule of THF $(0.80 \mathrm{~g}, 94 \%)$ as a colourless solid. The inclusion of a THF molecule in the solid was confirmed by the ${ }^{1} \mathrm{H}-\mathrm{NMR}$ spectroscopy, X-ray crystallography and elemental analysis. 3a: Colourless crystals, m.p. $154-159{ }^{\circ} \mathrm{C}$ (decomp.). ${ }^{1} \mathrm{H}$ NMR $(300$ $\left.\mathrm{MHz}, \mathrm{THF}-\mathrm{d}_{8}\right): \delta 3.59\left(\mathrm{~s}, 24 \mathrm{H}, \mathrm{CH}_{2}\right), 7.08-7.28(\mathrm{~m}, 2 \mathrm{H}, \mathrm{CH}), 7.32-$ $7.63(\mathrm{~m}, 5 \mathrm{H}, \mathrm{CH}), 8.70\left(\mathrm{t},{ }^{1} \mathrm{JHH}=9.5 \mathrm{~Hz}, 1 \mathrm{H}, \mathrm{CH}\right) .{ }^{11} \mathrm{~B}$ NMR (96 $\left.\mathrm{MHz}, \mathrm{THF}-\mathrm{d}_{8}\right): \delta-10.2\left(\mathrm{~d}, \mathrm{~J}_{\mathrm{PB}}=156 \mathrm{~Hz}\right)$. The ${ }^{13} \mathrm{C}\left\{{ }^{1} \mathrm{H}\right\}$ NMR data could not be obtained to a satisfactory standard due to poor solubility in THF- $d_{8}$ or Acetonitrile- $d_{3} .{ }^{19} \mathrm{~F}$ NMR $(282 \mathrm{MHz}$, THF$\left.d_{8}\right): \delta-171.79$ to $-172.09(\mathrm{~m}, 1 \mathrm{~F}),-171.46$ to $-171.48(\mathrm{~m}, 1 \mathrm{~F}),-$ 170.94 to $-171.51(\mathrm{~m}, 3 \mathrm{~F}),-170.20$ to $-170.50(\mathrm{~m}, 1 \mathrm{~F}),-167.15$ $\left(\mathrm{t}, J_{\mathrm{FF}}=20.4 \mathrm{~Hz}, 1 \mathrm{~F}\right),-166.94\left(\mathrm{t}, J_{\mathrm{FF}}=20.4 \mathrm{~Hz}, 1 \mathrm{~F}\right),-166.32$ (td, $\left.J_{\mathrm{FF}}=20.4,8.5 \mathrm{~Hz}, 1 \mathrm{~F}\right),-133.31$ to $-133.81(\mathrm{~m}, 1 \mathrm{~F}),-130.62$ to $131.00(\mathrm{~m}, 1 \mathrm{~F}),-126.75$ to $-127.18(\mathrm{~m}, 1 \mathrm{~F}),-123.89$ to -124.68 $(\mathrm{m}, 1 \mathrm{~F}),-122.71$ to $-123.28(\mathrm{~m}, 1 \mathrm{~F}),-121.56\left(\mathrm{dd}, \mathrm{J}_{\mathrm{FF}}=44.4,23.3\right.$ $\mathrm{Hz}, 1 \mathrm{~F}),-76.31$ to -76.80 (m, 6F), -74.76 (q, $\left.{ }^{4} J_{\mathrm{FF}}=11.0 \mathrm{~Hz}, 3 \mathrm{~F}\right)$, $-74.43\left(\mathrm{q},{ }^{4} \mathrm{JFF}_{\mathrm{FF}}=11.0 \mathrm{~Hz}, 3 \mathrm{~F}\right) .{ }^{31} \mathrm{P}$ NMR $\left(122 \mathrm{MHz}, \mathrm{THF}-d_{8}\right): \delta-$ $13.7\left(\mathrm{q}, \mathrm{J}_{\mathrm{PB}}=147 \mathrm{~Hz}\right) .{ }^{31} \mathrm{P}\left\{{ }^{1} \mathrm{H}\right\} \mathrm{NMR}\left(122 \mathrm{MHz}, \mathrm{THF}-d_{8}\right): \delta-13.7$ $\left(\mathrm{q}, \mathrm{J}_{\mathrm{PB}}=147 \mathrm{~Hz}\right)$. LRMS (ESI, negative) $\mathrm{m} / \mathrm{z}=1027([\mathrm{M}-$ $\left.\mathrm{C}_{12} \mathrm{H}_{24} \mathrm{KO}_{6}\right]^{-}$). Anal. Calcd for $\mathrm{C}_{48} \mathrm{H}_{32} \mathrm{BF}_{27} \mathrm{KO}_{8} \mathrm{P}+1$.0THF: C, 44.53; $H, 2.87$. Found: C, 44.16; $H, 3.04$.

\section{Synthesis of Tetrabutylammonium Phosphoranyl-borate (3b)}

Tetrabutylammonium phosphoranyl-borate $\mathbf{3 b}$ was synthesised from tetrabutylammonium phosphoranide $2 \mathrm{~b}(0.50 \mathrm{~g}, 0.66 \mathrm{mmol})$ similarly to the procedure for $3 a$, but using $\mathrm{C}_{6} \mathrm{H}_{6}$ instead of toluene as the reaction solvent. The crude product was recrystallised from THF/Et $\mathrm{t}_{2} \mathrm{O}$ to give $\mathbf{3 b}$ in $(0.84 \mathrm{~g}, 80 \%)$ as a colourless solid.

3b: Colourless crystals, m.p. $135-137^{\circ} \mathrm{C}$ (decomp.). ${ }^{1} \mathrm{H}$ NMR $(300$ $\left.\mathrm{MHz}, \mathrm{THF}-\mathrm{d}_{8}\right): \delta 0.99\left(\mathrm{t}, J=7.4 \mathrm{~Hz}, 12 \mathrm{H}, \mathrm{CH}_{3}\right), 1.32-1.47(\mathrm{~m}, 8 \mathrm{H}$, $\left.\mathrm{CH}_{2}\right), 1.60-1.76\left(\mathrm{~m}, 8 \mathrm{H}, \mathrm{CH}_{2}\right), 3.18-3.29\left(\mathrm{~m}, 8 \mathrm{H}, \mathrm{CH}_{2}\right), 7.10-7.27$ (m, 2H, CH), 7.34-7.62 (m, 5H, CH), $8.71(\mathrm{t}, J=9.3 \mathrm{~Hz}, 1 \mathrm{H}, \mathrm{CH})$. ${ }^{11} \mathrm{~B}$ NMR (96.3 MHz, THF- $\left.d_{8}\right): \delta-10.3\left(\mathrm{~d},{ }^{1} J_{\mathrm{BP}}=156 \mathrm{~Hz}\right)$. The ${ }^{13} \mathrm{C}\left\{{ }^{1} \mathrm{H}\right\}$ NMR data could not be obtained due to poor solubility in THF- $d_{8}$ or Acetonitrile- $d_{3} .{ }^{19} \mathrm{~F}$ NMR $\left(282 \mathrm{MHz}, \mathrm{THF}-d_{8}\right): \delta-171.83$ to $-172.10(\mathrm{~m}, 1 \mathrm{~F}),-171.52$ to $-171.78(\mathrm{~m}, 1 \mathrm{~F}),-170.94$ to $171.51(\mathrm{~m}, 3 \mathrm{~F}),-170.22$ to $-170.49(\mathrm{~m}, 1 \mathrm{~F}),-167.15\left(\mathrm{t}, \mathrm{JFF}_{\mathrm{FF}}=20.2\right.$ $\mathrm{Hz}, 1 \mathrm{~F}),-166.94\left(\mathrm{t}, J_{\mathrm{FF}}=20.6 \mathrm{~Hz}, 1 \mathrm{~F}\right),-166.32\left(\mathrm{td}, J_{\mathrm{FF}}=20.6\right.$, $8.5 \mathrm{~Hz}, 1 \mathrm{~F}),-133.33$ to $-133.78(\mathrm{~m}, 1 \mathrm{~F}),-130.62$ to $-130.98(\mathrm{~m}$, $1 \mathrm{~F}),-126.79$ to $-127.17(\mathrm{~m}, 1 \mathrm{~F}),-123.90$ to $-124.67(\mathrm{~m}, 1 \mathrm{~F}),-$ 122.78 to $-123.25(\mathrm{~m}, 1 \mathrm{~F}),-121.36$ to -121.78 (m, 1F), -76.32 to $-76.79(\mathrm{~m}, 6 \mathrm{~F}),-74.76\left(\mathrm{q},{ }^{4} \mathrm{JFF}_{\mathrm{FF}}=11.2 \mathrm{~Hz}, 3 \mathrm{~F}\right),-74.43$ (q, ${ }^{4} \mathrm{JFF}_{\mathrm{FF}}$ $=11.2 \mathrm{~Hz}, 3 \mathrm{~F}) \cdot{ }^{31} \mathrm{P}$ NMR $\left(122 \mathrm{MHz}, \mathrm{THF}-d_{8}\right): \delta-15.6$ (q, JPB $=146$ $\mathrm{Hz}$ ). ${ }^{31} \mathrm{P}\left\{{ }^{1} \mathrm{H}\right\}$ NMR (122 MHz, THF- $\left.d_{8}\right): \delta-15.6$ (q, JPB $=145 \mathrm{~Hz}$ ). MS (ESI, negative) $\mathrm{m} / \mathrm{z} 1027\left(\left[\mathrm{M}-\mathrm{N}\left(\mathrm{C}_{4} \mathrm{H}_{9}\right)_{4}\right]^{-}\right)$. Anal. Calcd for $\mathrm{C}_{52} \mathrm{H}_{44} \mathrm{BF}_{27} \mathrm{NO}_{2} \mathrm{P}$ : C, 49.19; $\mathrm{H}, 3.49$; N, 1.10. Found: C, 49.23; $\mathrm{H}$, $3.64 ; \mathrm{N}, 1.14$. 


\section{Synthesis of Phosphonium-borate 5 by Treatment of 1a with} Methyl Triflate

To a solution of $1 \mathrm{a}(0.50 \mathrm{~g}, 0.59 \mathrm{mmol})$ in toluene $(20 \mathrm{~mL})$ was added methyl triflate $(65 \mu \mathrm{L}, 0.59 \mathrm{mmol})$ and the reaction mixture was stirred at room temperature for 1 hour, then concentrated under reduced pressure to give a solid. The solid was dissolved in $\mathrm{Et}_{2} \mathrm{O}$, filtered through a bed of Celite and concentrated under reduced pressure to give a solid. The solid was recrystallised from $\mathrm{Et}_{2} \mathrm{O} /$ hexanes to give compound $\mathbf{5}$ as a colourless solid $(0.26 \mathrm{~g}$, $84 \%$ ). The spectra obtained on the product matched those previously reported. ${ }^{[33]}$

\section{General Procedure for Hydroboration of Alkynes and Alkenes with 4}

To a THF solution of 4 , prepared from $1 \mathrm{a}(250 \mathrm{mg}, 0.29 \mathrm{mmol})$ in THF (15 mL) according to the previously reported procedure ${ }^{[33]}$, was added freshly distilled alkene/alkyne (20 eq.) and the reaction mixture was stirred for $48 \mathrm{~h}$ at room temperature. The reaction mixture was diluted with $\mathrm{H}_{2} \mathrm{O}(20 \mathrm{~mL})$ and extracted with $\mathrm{CHCl}_{3}$ (x3). The combined organic extracts were washed with $\mathrm{H}_{2} \mathrm{O}$, dried over $\mathrm{MgSO}_{4}$ and concentrated under reduced pressure to give a residue. The residue was dissolved in a toluene/DMSO mixture $(10: 1,20 \mathrm{~mL})$ and $\mathrm{N}$-methyliminodiacetic acid (44 mg, $0.3 \mathrm{mmol})$ was added. The mixture was refluxed with a Dean-Stark apparatus attached under $\mathrm{N}_{2}$ for 16 hours, then cooled to room temperature. The solvent was removed under reduced pressure and the resulting residue was purified by flash chromatography $\left(0-20 \% \mathrm{MeCN} / \mathrm{Et}_{2} \mathrm{O}\right)$ to give a colourless solid of compounds 10 14.

(Z)-But-2-en-2-yI MIDA boronate (10). Compound 4 was treated with 2-butyne $(0.31 \mathrm{~g}, 5.8 \mathrm{mmol})$ according to the general procedure to give 10 as a solid ( $38 \mathrm{mg}, 60 \%$ ).

10: Colourless solid. ${ }^{1} \mathrm{H}$ NMR (300 MHz, Acetone- $\left.d_{6}\right): \delta 1.62$ (s, $\left.3 \mathrm{H}, \mathrm{CH}_{3}\right), 1.66$ (d, J = 6.5 Hz, 3H, $\mathrm{CH}_{3}$ ), 2.94 (s, $\mathrm{NCH}_{3}$ ), 3.99 (d, $\left.J=16.8 \mathrm{~Hz}, 2 \mathrm{H}, \mathrm{CH}_{2}\right), 4.17$ (d, $J=16.8 \mathrm{~Hz}, 2 \mathrm{H}, \mathrm{CH}_{2}$ ), 5.91 (br q, $J=6.5 \mathrm{~Hz}, 1 \mathrm{H}, \mathrm{CH}) .{ }^{11} \mathrm{~B}\left\{{ }^{1} \mathrm{H}\right\} \mathrm{NMR}\left(96.3 \mathrm{MHz}\right.$, Acetone- $\left.d_{6}\right): \delta 11.1$ (s). ${ }^{13} \mathrm{C}\left\{{ }^{1} \mathrm{H}\right\} \mathrm{NMR}\left(75 \mathrm{MHz}\right.$, Acetone- $\left.d_{6}\right): \delta 14.1\left(\mathrm{~s}, \mathrm{CH}_{3}\right), 14.3$ (s, $\left.\mathrm{CH}_{3}\right), 47.0\left(\mathrm{~s}, \mathrm{CH}_{3}\right), 62.5\left(\mathrm{CH}_{2}\right), 133.4(\mathrm{CH}), 169.3\left(\mathrm{C}_{\mathrm{q}}\right)$. MS (ESI, positive) $\mathrm{m} / \mathrm{z} 212.1\left([\mathrm{M}+\mathrm{H}]^{+}\right)$.

(E)-Hept-1-en-1-yI MIDA boronate (11a) and (E)-hept-1-en-2-yI MIDA boronate (11b). Compound 4 was treated with 1-heptyne $(0.56 \mathrm{~g}, 5.8 \mathrm{mmol})$ according to the general procedure to give $11 \mathrm{a}$ and $11 \mathrm{~b}$ as a solid that contained an inseparable mixture of isomers (7:3 ratio, $52 \mathrm{mg}, 68 \%$ ). 11a, 11b: Colourless solid. ${ }^{1} \mathrm{H}$ NMR $\left(300 \mathrm{MHz}, \mathrm{CDCl}_{3}\right)$ : 11a $\delta 0.87$ $\left(\mathrm{t}, J=6.8 \mathrm{~Hz}, 3 \mathrm{H}, \mathrm{CH}_{3}\right), 1.17-1.54\left(\mathrm{~m}, 6 \mathrm{H}, \mathrm{CH}_{2}\right), 2.11$ (q, $J=6.5$ $\left.\mathrm{Hz}, 2 \mathrm{H}, \mathrm{CH}_{2}\right), 2.82\left(\mathrm{~s}, 3 \mathrm{H}, \mathrm{NCH}_{3}\right), 3.69\left(\mathrm{~d}, J=16.8 \mathrm{~Hz}, 2 \mathrm{H}, \mathrm{CH}_{2}\right.$ ), 4.02 (d, $J=16.8 \mathrm{~Hz}, 2 \mathrm{H}, \mathrm{CH}_{2}$ ), 5.37 (d, J=17.6 Hz, 1H, CH), 6.16 (dt, $J=17.6 \mathrm{~Hz}, 1 \mathrm{H}, \mathrm{CH}$ ); 11b $\delta 0.87$ (t, $J=6.8 \mathrm{~Hz}, 3 \mathrm{H}, \mathrm{CH}_{3}$ ), 1.17-1.54 (m, 6H, CH $), 1.98$ (t, $\left.J=7.4 \mathrm{~Hz}, 2 \mathrm{H}, \mathrm{CH}_{2}\right), 2.81(\mathrm{~s}, 3 \mathrm{H}$, $\left.\mathrm{NCH}_{3}\right), 3.74\left(\mathrm{~d}, J=16.8 \mathrm{~Hz}, 2 \mathrm{H}, \mathrm{CH}_{2}\right), 4.04(\mathrm{~d}, J=16.8 \mathrm{~Hz}, 2 \mathrm{H}$, $\mathrm{CH}_{2}$ ), 5.34 (br s, $\left.1 \mathrm{H}, \mathrm{CH}\right), 5.40$ (br s, $\left.1 \mathrm{H}, \mathrm{CH}\right) .{ }^{11} \mathrm{~B} \mathrm{NMR}(96.3 \mathrm{MHz}$, $\left.\mathrm{CDCl}_{3}\right): \delta 12.6$ (br s). ${ }^{13} \mathrm{C}\left\{{ }^{1} \mathrm{H}\right\} \mathrm{NMR}\left(75 \mathrm{MHz}, \mathrm{CDCl}_{3}\right): 11 \mathrm{a} \delta 14.1$ (s, $\left.\mathrm{CH}_{3}\right), 22.6\left(\mathrm{~s}, \mathrm{CH}_{2}\right), 28.5\left(\mathrm{~s}, \mathrm{CH}_{2}\right), 31.6\left(\mathrm{~s}, \mathrm{CH}_{2}\right), 35.6\left(\mathrm{~s}, \mathrm{CH}_{2}\right)$, $47.0\left(\mathrm{~s}, \mathrm{CH}_{3}\right), 61.5\left(\mathrm{~s}, \mathrm{CH}_{2}\right), 123.6(\mathrm{br} \mathrm{s}, \mathrm{CH}), 148.0(\mathrm{~s}, \mathrm{CH}), 168.5$ (s, $\left.\mathrm{C}_{\mathrm{q}}\right) ; 11 \mathrm{~b} \delta 14.2\left(\mathrm{~s}, \mathrm{CH}_{3}\right), 22.7\left(\mathrm{~s}, \mathrm{CH}_{2}\right), 28.5\left(\mathrm{~s}, \mathrm{CH}_{2}\right), 31.9(\mathrm{~s}$, $\mathrm{CH}_{2}$ ), 34.7 (s, $\mathrm{CH}_{2}$ ), 46.9 (s, $\left.\mathrm{CH}_{3}\right), 61.9$ (s, $\left.\mathrm{CH}_{2}\right), 123.9$ (s, $\mathrm{CH}_{2}$ ), $168.6\left(\mathrm{~s}, C_{\mathrm{q}}\right)$. The carbon connected to the boron atom was not observed for 11b due to quadrupolar line broadening. MS (ESI, positive) $m / z 254.1\left([\mathrm{M}+\mathrm{H}]^{+}\right)$.

(E)-Styryl MIDA boronate (12a) and 1-phenylvinyl MIDA boronate (12b). Compound 4 was treated with phenylacetylene $(0.59 \mathrm{~g}, 5.8 \mathrm{mmol})$ according to the general procedure to give $12 \mathrm{a}$ (28 mg, 36\%) and 12b (20 mg, 26\%) as solids.

12a: Colourless solid. ${ }^{1} \mathrm{H}$ NMR $\left(300 \mathrm{MHz}\right.$, Acetone- $\left.d_{6}\right): \delta 3.06$ (s, $\left.3 \mathrm{H}, \mathrm{CH}_{3}\right), 4.09$ (d, $J=16.8 \mathrm{~Hz}, 2 \mathrm{H}, \mathrm{CH}_{2}$ ), 4.26 (d, $J=16.8 \mathrm{~Hz}, 2 \mathrm{H}$, $\left.\mathrm{CH}_{2}\right), 6.35(\mathrm{~d}, \mathrm{~J}=18.2 \mathrm{~Hz}, 1 \mathrm{H}, \mathrm{CH}), 6.96(\mathrm{~d}, J=18.2 \mathrm{~Hz}, 1 \mathrm{H}, \mathrm{CH}$ ), 7.21-7.38 (m, 3H), 7.48-7.55 (m, 2H). ${ }^{11} \mathrm{~B}$ NMR (96.3 MHz, Acetone- $\left.d_{6}\right): \delta 11.0$ (br s). ${ }^{13} \mathrm{C}\left\{{ }^{1} \mathrm{H}\right\}$ NMR (75 MHz, Acetone- $\left.d_{6}\right): \delta$ $47.4\left(\mathrm{~s}, \mathrm{CH}_{3}\right), 62.4\left(\mathrm{~s}, \mathrm{CH}_{2}\right) 127.5(\mathrm{~s}, \mathrm{CH}), 128.7(\mathrm{~s}, \mathrm{CH}), 129.4$ (s, $\mathrm{CH}), 139.2$ (s, $\left.\mathrm{C}_{\mathrm{q}}\right), 142.9$ (s, CH), 169.1 (s, $\left.\mathrm{C}_{\mathrm{q}}\right)$. The carbon connected to the boron atom was not observed for $12 \mathrm{a}$ due to quadrupolar line broadening. MS (ESI, positive) $\mathrm{m} / \mathrm{z} 260.1$ ([M + $\mathrm{H}^{+}$). Spectral data for $12 \mathrm{a}$ were consistent with those previously reported in the literature. ${ }^{[72]}$

12b: Colourless solid. ${ }^{1} \mathrm{H}$ NMR (300 MHz, Acetone- $\left.d_{6}\right): \delta 2.82$ (s, $\left.3 \mathrm{H}, \mathrm{CH}_{3}\right), 3.84\left(\mathrm{~d}, \mathrm{~J}=16.8 \mathrm{~Hz}, 2 \mathrm{H}, \mathrm{CH}_{2}\right), 4.22(\mathrm{~d}, \mathrm{~J}=16.8 \mathrm{~Hz}, 2 \mathrm{H}$, $\mathrm{CH}_{2}$ ), 5.69 (br s, 1H, CH), $5.73(\mathrm{br} \mathrm{d}, J=3.0 \mathrm{~Hz}, 1 \mathrm{H}, \mathrm{CH}), 7.19-$ $7.36(\mathrm{~m}, 3 \mathrm{H}), 7.37-7.46(\mathrm{~m}, 2 \mathrm{H}) .{ }^{11} \mathrm{~B}$ NMR $(96.3 \mathrm{MHz}$, Acetone$\left.d_{6}\right): \delta 10.7$ (br s). ${ }^{13} \mathrm{C}\left\{{ }^{1} \mathrm{H}\right\}$ NMR (75 MHz, Acetone- $\left.d_{6}\right): \delta 47.7$ (s, $\mathrm{CH}_{3}$ ), 62.8 (s, $\left.\mathrm{CH}_{2}\right) 127.4$ (s, $\mathrm{CH}$ ), 128.1 (s, $\left.\mathrm{CH}_{2}\right), 128.4(\mathrm{~s}, \mathrm{CH})$, 129.2 (s, CH), 145.4 (s, $\left.C_{\mathrm{q}}\right), 168.9$ (s, $\left.C_{\mathrm{q}}\right)$. The carbon connected to the boron atom was not observed for $12 \mathrm{~b}$ due to quadrupolar line broadening. MS (ESI, positive) $\mathrm{m} / \mathrm{z} 260.1\left([\mathrm{M}+\mathrm{H}]^{+}\right)$. Spectral data for $\mathbf{1 2 b}$ were consistent with those previously reported in the literature. ${ }^{\text {[7] }}$

Hexan-1-yl MIDA boronate (13a) and hexan-2-yl MIDA boronate (13b). Compound 4 was treated with 1-hexene $(0.49 \mathrm{~g}$, $5.8 \mathrm{mmol}$ ) according to the general procedure to give $13 \mathrm{a}$ and $13 \mathrm{~b}$ 
as a solid that contained an inseparable mixture of isomers (3:1 ratio, $36 \mathrm{mg}, 49 \%)$.

13a, 13b: Colourless solid. ${ }^{1} \mathrm{H}$ NMR (300 MHz, Acetone- $\left.d_{6}\right)$ : 13a $\delta 0.63$ (br t, $J=7.5 \mathrm{~Hz}, 2 \mathrm{H}, \mathrm{CH}_{2}$ ), 0.88 (t, $J=7.0 \mathrm{~Hz}, 3 \mathrm{H}, \mathrm{CH}_{3}$ ), 1.22-1.42 (m, 8H, $\left.\mathrm{CH}_{2}\right), 3.07$ (s, 3H, NCH3), $3.99(\mathrm{~d}, J=16.8 \mathrm{~Hz}$, $\left.2 \mathrm{H}, \mathrm{CH}_{2}\right), 4.16\left(\mathrm{~d}, \mathrm{~J}=16.8 \mathrm{~Hz}, 2 \mathrm{H}, \mathrm{CH}_{2}\right) ; 13 \mathrm{~b} \delta 0.84-0.93(\mathrm{~m}, 7 \mathrm{H}$, $\left.2 \times \mathrm{CH}_{3}, \mathrm{CH}\right), 1.22-1.42\left(\mathrm{~m}, 6 \mathrm{H}, \mathrm{CH}_{2}\right), 3.13\left(\mathrm{~s}, 3 \mathrm{H}, \mathrm{NCH}_{3}\right), 4.01$ (d, $\left.J=16.8 \mathrm{~Hz}, 2 \mathrm{H}, \mathrm{CH}_{2}\right), 4.17$ (d, $\left.J=16.8 \mathrm{~Hz}, 2 \mathrm{H}, \mathrm{CH}_{2}\right) .{ }^{11} \mathrm{~B}$ NMR (96.3 MHz, Acetone- $d_{6}$ ): $\delta 13.2$ (br s). ${ }^{13} \mathrm{C}\left\{{ }^{1} \mathrm{H}\right\}$ NMR (75 MHz, Acetone- $\left.d_{6}\right)$ : 13a $\delta 14.4\left(\mathrm{~s}, \mathrm{CH}_{3}\right), 23.3\left(\mathrm{~s}, \mathrm{CH}_{2}\right), 25.0\left(\mathrm{~s}, \mathrm{CH}_{2}\right), 32.5$ (s, $\mathrm{CH}_{2}$ ), 33.4 (s, $\mathrm{CH}_{2}$ ), 46.2 (s, $\mathrm{CH}_{3}$ ), 62.7 (s, $\mathrm{CH}_{2}$ ), 63.4 (d, $\mathrm{JBC}_{\mathrm{BC}}=$ $\left.9.0 \mathrm{~Hz}, \mathrm{CH}_{2}\right), 168.8\left(\mathrm{C}_{\mathrm{q}}\right) ;$ 13b $\delta 14.5\left(\mathrm{~s}, \mathrm{CH}_{3}\right), 14.7\left(\mathrm{~s}, \mathrm{CH}_{3}\right), 23.7$ (s, $\mathrm{CH}_{2}$ ), 31.2 (s, $\mathrm{CH}_{2}$ ), 32.7 (s, $\mathrm{CH}_{2}$ ), 46.2 (s, $\left.\mathrm{CH}_{3}\right), 62.7\left(\mathrm{~s}, \mathrm{CH}_{2}\right)$, $168.8\left(C_{\mathrm{q}}\right)$. The carbon connected to the boron atom was not observed for $13 \mathrm{~b}$ due to quadrupolar line broadening. MS (ESI, positive) $m / z 242.1\left([\mathrm{M}+\mathrm{H}]^{+}\right)$.

Phenethyl MIDA boronate (14a) and 1-phenylethyl MIDA boronate (14b). Compound 4 was treated with styrene $(0.60 \mathrm{~g}$, $5.8 \mathrm{mmol}$ ) according to the general procedure to give $14 \mathrm{a}$ and $14 \mathrm{~b}$ as a solid that contained an inseparable mixture of isomers (9:1 ratio, $52 \mathrm{mg}, 38 \%$ ).

14a, 14b: Colourless solid. ${ }^{1} \mathrm{H}$ NMR (300 MHz, Acetone- $\left.d_{6}\right)$ : 14a $\delta$ 0.92-1.05 (m, 2H, CH$), 2.62-2.72\left(\mathrm{~m}, 2 \mathrm{H}, \mathrm{CH}_{2}\right), 3.12(\mathrm{~s}, 3 \mathrm{H}$, $\left.\mathrm{NCH}_{3}\right), 4.05$ (d, $\left.J=16.8 \mathrm{~Hz}, 2 \mathrm{H}, \mathrm{CH}_{2}\right), 4.22(\mathrm{~d}, J=16.8 \mathrm{~Hz}, 2 \mathrm{H}$, $\left.\mathrm{CH}_{2}\right), 7.06-7.18(\mathrm{~m}, 1 \mathrm{H}, \mathrm{CH}), 7.19-7.34(\mathrm{~m}, 4 \mathrm{H}, \mathrm{CH}) .14 \mathrm{~b} \delta 0.82-$ $0.92\left(\mathrm{~m}, 3 \mathrm{H}, \mathrm{CH}_{3}\right), 3.01$ (s, 3H, NCH 3$), 4.05$ (d, $J=16.8 \mathrm{~Hz}, 2 \mathrm{H}$, $\left.\mathrm{CH}_{2}\right), 4.18\left(\mathrm{~d}, J=16.8 \mathrm{~Hz}, 2 \mathrm{H}, \mathrm{CH}_{2}\right), 7.06-7.18(\mathrm{~m}, 1 \mathrm{H}, \mathrm{CH})$, 7.19-7.34 (m, 4H, CH). ${ }^{11} \mathrm{~B}$ NMR (96.3 MHz, Acetone- $\left.d_{6}\right): \delta 12.9$ (br s). ${ }^{13} \mathrm{C}\left\{{ }^{1} \mathrm{H}\right\}$ NMR (300 MHz, Acetone- $\left.d_{6}\right)$ : 14a $\delta 31.2\left(\mathrm{~s}, \mathrm{CH}_{2}\right)$, 46.4 (s, $\mathrm{CH}_{3}$ ), 62.8 (s, $\mathrm{CH}_{2}$ ), 63.3 (d, $\left.\mathrm{JBC}_{\mathrm{BC}}=8.4 \mathrm{~Hz}, \mathrm{CH}_{2}\right), 126.1$ (s, $\mathrm{CH}), 128.7$ (s, CH), 129.1 (s, CH), 146.4 (s, $\left.\mathrm{C}_{\mathrm{q}}\right) 168.9$ (s, $\left.\mathrm{C}_{\mathrm{q}}\right) ; 14 \mathrm{~b}$ $\delta 19.0$ (s, $\left.\mathrm{CH}_{3}\right), 46.3\left(\mathrm{~s}, \mathrm{CH}_{3}\right), 62.8\left(\mathrm{~s}, \mathrm{CH}_{2}\right), 125.9(\mathrm{~s}, \mathrm{CH}), 129.2$ (s, CH), 129.3 (s, CH), 168.9 (s, $C_{\mathrm{q}}$ ). MS (ESI, negative) $\mathrm{m} / \mathrm{z} 262.1$ The $\mathrm{CH}$ peak of $14 \mathrm{~b}$ in the ${ }^{1} \mathrm{H}$ NMR spectrum could not be observed due to it overlapping with the $\mathrm{CH}_{2}$ multiplet peak of 14a between $0.92-1.05 \mathrm{ppm}$. The quaternary carbon of the aromatic ring and the carbon next to the boron atom were not observed for 14b due to its low abundance in the sample and quadrupolar line broadening, respectively.

\section{X-ray Crystallographic Analysis}

Colourless single crystals were obtained by recrystallisation from $\mathrm{C}_{6} \mathrm{H}_{6}$ at room temperature for $1 \mathrm{a}, \mathrm{THF} \mathrm{Et}_{2} \mathrm{O}$ at $-35^{\circ} \mathrm{C}$ for $3 \mathrm{a}$ and at room temperature for $\mathbf{3 b}$, and $\mathrm{Et}_{2} \mathrm{O} /$ hexanes at $-35^{\circ} \mathrm{C}$ for $\mathbf{6}$. The single crystals were used for $\mathrm{X}$-ray diffraction data collection on a Rigaku Mercury charge-coupled device diffractometer with a graphite-monochromated Mo-K $\alpha$ radiation. Data was collected and processed using CrystalClear (Rigaku). The data was corrected for Lorentz and polarisation effects. The structures were solved by direct methods (SHELXS-97) and expanded using Fourier techniques. ${ }^{[7]}$ The non-hydrogen atoms were refined anisotropically. Hydrogen atoms on the boron atom of $1 \mathrm{a}$ and on the phosphorus atom of $\mathbf{6}$ were assigned by Fourier method and refined isotropically. All other hydrogen atoms were assigned by calculation and refined isotropically by using a riding model. Selected crystal data are summarised below.

1a: $\mathrm{C}_{30} \mathrm{H}_{35} \mathrm{BF}_{12} \mathrm{KO}_{8} \mathrm{P} \cdot \mathrm{C}_{6} \mathrm{H}_{6}, M=910.57$, monoclinic, space group $P 21 / \mathrm{n}, a=8.400(3), b=26.682(9), c=18.660(6) \AA, \beta=92.259(3)^{\circ}$, $V=4179(2) \AA^{3}, Z=4, D_{\mathrm{c}}=1.447 \mathrm{~g} \mathrm{~cm}^{-3}, \mu=0.266 \mathrm{~mm}^{-1}, T=$ $133(2) \mathrm{K}, 9506$ reflections measured, 7824 unique, final $R 1$ ( $>$ $2 \sigma(I))=0.0393, \mathrm{wR2}($ all data $)=0.0960, \mathrm{GOF}=1.060$.

3a: $\mathrm{C}_{52} \mathrm{H}_{40} \mathrm{BF}_{27} \mathrm{KO}_{9} \mathrm{P}, M=1402.72$, triclinic, space group $P-1, a=$ 14.8793(19), $b=18.318(2), c=21.841(3) \AA, \alpha=71.928(3), \beta=$ 78.948(4), $\gamma=88.026(5)^{\circ}, V=5552.2(12) \AA^{3}, Z=4, D_{\mathrm{c}}=1.678 \mathrm{~g}$ $\mathrm{cm}^{-3}, \mu=0.272 \mathrm{~mm}^{-1}, T=113(2) \mathrm{K}, 24354$ reflections measured, 18657 unique, final $R 1(I>2 \sigma(I))=0.0584$, wR2 (all data) $=$ 0.1551, GOF $=1.083$.

3b: $\mathrm{C}_{36} \mathrm{H}_{8} \mathrm{BF}_{27} \mathrm{O}_{2} \mathrm{P} \cdot \mathrm{C}_{16} \mathrm{H}_{36} \mathrm{~N}, M=1269.66$, triclinic, space group $P-1, a=11.0027(12), b=13.1239(14), c=18.828(2) \AA, \alpha=$ $95.2712(14)^{\circ}, \beta=101.9873(12)^{\circ}, \gamma=98.0208(15)^{\circ}, V=2612.8(5)$ $\AA^{3}, Z=2, D_{\mathrm{c}}=1.614 \mathrm{~g} \mathrm{~cm}^{-3}, \mu=0.193 \mathrm{~mm}^{-1}, T=133(2) \mathrm{K}, 11312$ reflections measured, 9900 unique, final $R 1(I>2 \sigma(I))=0.0349$, $\mathrm{WR2}($ all data $)=0.0913, \mathrm{GOF}=1.032$.

6: $\mathrm{C}_{22} \mathrm{H}_{16} \mathrm{BF}_{12} \mathrm{O}_{2} \mathrm{P}, M=582.13$, monoclinic, space group $P 2_{1} / \mathrm{n}$, a $=11.4558(14), b=12.8592(13), c=15.6289(19) \AA, \beta=94.821(7)^{\circ}$, $V=2294.2(5) \AA^{3}, Z=4, D_{\mathrm{c}}=1.685 \mathrm{~g} \mathrm{~cm}^{-3}, \mu=0.238 \mathrm{~mm}^{-1}, T=$ $113(2) \mathrm{K}, 5101$ reflections measured, 3784 unique, final $R 1(I>$ $2 \sigma(I))=0.0781, w R 2($ all data $)=0.2522$, GOF $=1.132$.

Additional crystal data are available at the Cambridge Crystallographic Data Centre, deposition no. CCDC 1938562 (1a), CCDC 1938563 (3a), CCDC 1938564 (3b) and CCDC 1938565 (6).

\section{Variable Temperature ${ }^{19} \mathrm{~F}$ NMR Experiment with Phosphoranyl-Trihydroborate 1a}

Phosphoranyl-trihydroborate $1 \mathrm{a}(15 \mathrm{mg}, 0.01 \mathrm{mmol})$ was dissolved in THF- $d_{8}(400 \mu \mathrm{L})$ and analysed by variable temperature ${ }^{19} \mathrm{~F}$ NMR spectroscopy. The sample was first analysed using $5{ }^{\circ} \mathrm{C}$ increments from +30 to $+60{ }^{\circ} \mathrm{C}$, and then from -80 to $-40{ }^{\circ} \mathrm{C}$ (See Supporting Information, Figures S38 and S39). 


\section{Acknowledgements}

This work was partially supported by the grants from Toray Science Foundation, Asahi Glass Foundation, Izumi Science and Technology Foundation, Yamada Science Foundation, and Grants-in-Aid for Scientific Research (No. 24245005, 26105733, 15H00920, 15H00938 and 15H02158).

Keywords: phosphorus • boron • structure elucidation • hydroboration $\cdot$ X-ray crystallography

[1] H. Schmidbaur, J. Organomet. Chem. 1980, 200, 287.

P. P. Power, Angew. Chem. Int. Ed. Engl. 1990, 29, 449.

[3] T. Imamoto, Pure Appl. Chem. 1993, 65, 655

[4] A. Staubitz, A. P. M. Robertson, M. E. Sloan, I. Manners, Chem. Rev. 2010, 110, 4023.

[5] T. Imamoto, T. Kusumoto, N. Suzuki, K. Sato, J. Am. Chem. Soc. 1985, 107, 5301

[6] T. Imamoto, T. Oshiki, T. Onozawa, T. Kusumoto, K. Sato, J. Am. Chem. Soc. 1990, 112, 5244

T. Imamoto, Pure Appl Chem 2001, 73, 373.

[8] T. Imamoto, K. Tamura, Z. Zhang, Y. Horiuchi, M. Sugiya, K Yoshida, A. Yanagisawa, I. D. Gridnev, J. Am. Chem. Soc. 2012, 134,1754

[9] D. Moulin, S. Bago, C. Bauduin, C. Darcel, S. Jugé, TetrahedronAsymmetry 2000, 11, 3939

[10] H. Dorn, R. A. Singh, J. A. Massey, A. J. Lough, I. Manners, Angew. Chem. Int. Ed. 1999, 38, 3321

[11] T. J. Clark, J. M. Rodezno, S. B. Clendenning, S. Aouba, P. M. Brodersen, A. J. Lough, H. E. Ruda, I. Manners, Chem. Eur. J. 2005, 11, 4526

[12] S. Pandey, P. Lönnecke, E. Hey-Hawkins, Eur. J. Inorg. Chem. 2014, 2456

[13] R. T. Paine, H. Nöth, Chem. Rev. 1995, 95, 343

[14] S. J. Geier, T. M. Gilbert, D. W. Stephan, J. Am. Chem. Soc. 2008 130, 12632.

[15] S. J. Geier, T. M. Gilbert, D. W. Stephan, Inorg. Chem. 2011, 50, 336.

[16] J. H. W. LaFortune, Z.-W. Qu, K. L. Bamford, A. Trofimova, S. A Westcott, D. W. Stephan, Chem. Eur. J. 2019, 25, 12063.

[17] N. Szynkiewicz, A. Ordyszewska, J. Chojnacki, R. Grubba, RSC Adv. 2019, 9, 27749

[18] A. Amgoune, S. Ladeira, K. Miqueu, D. Bourissou, J. Am. Chem Soc. 2012, 134, 6560

[19] S. J. Geier, J. H. W. LaFortune, D. Zhu, S. C. Kosnik, C. L. B. Macdonald, D. W. Stephan, S. A. Westcott, Dalton Trans. 2017, 46, 10876.

[20]

S. J. Geier, C. M. Vogels, N. R. Mellonie, E. N. Daley, A. Deckan, S. Doherty, S. A. Westcott, Chem. Eur. J. 2017, 23, 14485.

[21] E. N. Daley, C. M. Vogels, S. J. Geier, A. Deckan, S. Doherty, S. A. Westcott, Angew. Chem. Int. Ed. 2015, 54, 2121

[22] J. H. W. LaFortune, A. Trofimova, H. Cummings, S. A. Westcott, D. W. Stephan, Chem. Eur. J. 2019, 25, 12521.

[23] J.-P. Finet, Ligand Coupling Reactions with Heteroatomic Compounds, Pergamon, Oxford, 1998, pp. 95-106.

[24] R. R. Holmes, Chem. Rev. 1996, 96, 927.

[25] K. C. Kumara Swamy, N. Satish Kumar, Acc. Chem. Res. 2006, 39 K. C.

[26] D. Krasowka, J. Chrzanowski, P. Kiełbasiński, J. Drabowicz, Molecules 2016, 21, 1573.

[27] L. A. Peacock, R. A. Geanangel, Inorg. Chem. 1976, 15, 244

[28] B. Garrigues, L. Lamandé, A. Munoz, Phosphorus Sulfur Relat. Elem. 1988, 35, 309.

[29] G. R. J. Thatcher, A. S. Campbell, J. Org. Chem. 1993, 58, 2272.

[30] S. Jugé, M. Stephan, R. Merdès, J. P. Genet, S. Halut-Desportes, J. Chem. Soc. Chem. Commun. 1993, 531.

[31] M. B. Tollefson, J. J. Li, P. Beak, J. Am. Chem. Soc. 1996, 118, 9052.

[32] J. Uziel, M. Stéphan, E. B. Kaloun, J. P. Genêt, S. Jugé, Bull. Soc. Chim. Fr. 1997, 134, 379.

[33] N. Kano, N. J. O’Brien, R. Uematsu, R. Ramozzi, K. Morokuma, Angew. Chem. Int. Ed. 2017, 56, 5882.

L. J. Adzima, J. C. Martin, J. Org. Chem. 1977, 42, 4006.

[35] E. F. Perozzi, J. C. Martin, J. Am. Chem. Soc. 1979, 101, 1591.

[36] E. F. Perozzi, R. S. Michalak, G. D. Figuly, W. H. Stevenson III, D. B. Dess, M. R. Ross, J. C. Martin, J. Org. Chem. 1981, 46, 1049. S. Kojima, K. Kajiyama, K.-y. Akiba, Tetrahedron Lett. 1994, 35, 7037.

[38] T. Kawashima, K. Watanabe, R. Okazaki, Tetrahedron Lett. 1997
38, 551 .

S. Matsukawa, S. Kojima, K. Kajiyama, Y. Yamamoto, K.-y. Akiba, S. Re, S. Nagase, J. Am. Chem. Soc. 2002, 124, 13154.

H. Miyake, N. Kano, T. Kawashima, J. Am. Chem. Soc. 2009, 131 16622.

I. Granoth, J. C. Martin, J. Am. Chem. Soc. 1979, 101, 4623.

M. R. Ross, J. C. Martin, J. Am. Chem. Soc. 1981, 103, 1234

S. K. Chopra, J. C. Martin, Heteroat. Chem. 1991, 2, 71.

Y. Okamoto, Y. Takei, K. Takagi, Polyhedron 1987, 6, 2119

C. M. Vogels, S. A. Westcott, Chem. Soc. Rev. 2011, 40, 1446.

T. Adachi, S. Matsukawa, M. Nakamoto, K. Kajiyama, S. Kojima, Y.

Yamamoto, K.-y. Akiba, S. Re, S. Nagase, Inorg. Chem. 2006, 45

7269 .

D. W. Stephan, G. Erker, Angew. Chem. Int. Ed. 2015, 54, 6400.

D. W. Stephan, Acc. Chem. Res. 2015, 48, 306.

H. Jacobsen, H. Berke, S. Döring, G. Kehr, G. Erker, R. Fröhlich, O. Meyer, Organometallics 1999, 18, 1724.

S. Kojima, M. Nakamoto, S. Matsukawa, K.-y. Akiba, Heteroat. Chem. 2011, 22, 491

K. Toyota, Y. Yamamoto, K.-y. Akiba, J. Chem. Res. Synop. 1999, 386

S. Kojima, K. Kajiyama, M. Nakamoto, S. Matsukawa, K.-y. Akiba, Eur. J. Org. Chem. 2006, 218.

A. H. Cowley, M. C. Damasco, J. Am. Chem. Soc. 1971, 93, 6815

A. E. Reed, R. B. Weinstock, F. Weinhold, J. Chem. Phys. 1985, 83 735.

R. F. W. Bader, Atoms in Molecules: A Quantum Theory, Claredon Press, Oxford, 1990

J.-M. Mörsdorf, H. Wadepohl, J. Ballmann, Inorg. Chem. 2019, 58, 3502.

E. P. Gillis, M. D. Burke, J. Am. Chem. Soc. 2007, 129, 6716 J. W. Lehmann, D. J. Blair, M. D. Burke, Nat. Rev. Chem. 2018, 2 0115.

S. Gamsey, K. DeLaTorre, B. Singaram, Tetrahedron-Asymmetry 2005, 16, 711 .

C. E. Tucker, J. Davidson, P. Knochel, J. Org. Chem. 1992, 57, 3482.

P. V. Ramachandran, J. S. Chandra, A. Ros, R. Fernández, J. M. Lassaletta, V. K. Aggarwal, D. J. Blair, E. L. Myers, Pinacolborane. in Encyclopedia of Reagents for Organic Synthesis., 2017.

H. C. Brown, S. K. Gupta, J. Am. Chem. Soc. 1971, 93, 1816.

H. C. Brown, S. K. Gupta, J. Am. Chem. Soc. 1972, 94, 4370. H. C. Brown, S. K. Gupta, J. Am. Chem. Soc. 1975, 97, 5249

A. Suzuki, R. S. Dhillon, Top. Curr. Chem. 1986, 130, 23.

R. H. Fish, J. Org. Chem. 1973, 38, 158.

E.-I. Negishi, H. C. Brown, Synthesis (Stuttg). 1974, 77

A. Pelter, K. Smith, H. C. Brown, Borane Reagents, Academic Press, New York, 1988.

A. Prokofjevs, A. Boussonnière, L. Li, H. Bonin, E. Lacôte, D. P. Curran, E. Vedejs, J. Am. Chem. Soc. 2012, 134, 12281.

X. Pan, A. Boussonnière, D. P. Curran, J. Am. Chem. Soc. 2013, $135,14433$.

V. Nesterov, D. Reiter, P. Bag, P. Frisch, R. Holzner, A. Porzelt, S. Inoue, Chem. Rev. 2018, 118, 9678.

M. Lüthy, R. J. K. Taylor, Tetrahedron Lett. 2012, 53, 3444.

E. M. Woerly, J. E. Miller, M. D. Burke, Tetrahedron 2013, 69, 7732.

G. M. Sheldrick, Acta Cryst. 2008, A64, 112. 